Foro, Nueva época, vol. 21, núm. 2 (2018): 437-464

ISSN:1698-5583

http://dx.doi.org/10.5209/FORO.64034

\title{
ESTADO DE DERECHO Y PLURALIDAD TERRITORIAL: EL VALOR INTANGIBLE DE LA DEMOCRACIA
}

\author{
José Antonio SAnz Moreno \\ Sección Departamental de Derecho Constitucional \\ Facultad de Ciencias Políticas y Sociología \\ Universidad Complutense de Madrid \\ jasanzmo@ucm.es
}

\begin{abstract}
RESUMEN
La angustia territorial del Estado de Derecho español —como unidad plural de la Nación con derecho a la autonomía de sus nacionalidades y regiones- se resuelve desde la defensa intangible de su Constitución: el autogobierno interno de las Comunidades Autónomas no conlleva ningún derecho de autodeterminación externa, y, sin embargo, debemos afrontar el órdago de la sinrazón nacional-populista, subrayando la cláusula de intangibilidad material del texto constitucional en una ya imprescindible revisión federal de nuestro Estado social y democrático.
\end{abstract}

Palabras clave: Derecho constitucional, democracia intangible, autodeterminación, populismo, Rule of Law.

\section{ABSTRACT}

Territorial anguish of Spanish Rule of Law - as a plural unity of the Nation with «the right to self-government of the nationalities and regions»- is resolved from an intangible protection of its Constitution: internal self-government of Autonomous Communities does not mean an external right to self-determination. However, we must fight the tremendous nonsense of national populism, underlining the material intangibility of Spanish Constitution with the federal development of our social and democratic State.

Keywords: Constitutional Law, intangible democracy, self-determination, populism, Rule of Law.

\section{ZUSSAMENFASSUNG}

Die territoriale Not des spanischen Rechtsstaats - als pluraler Einheit der Nation mit Recht auf Autonomie seiner Nationalitäten und Regionen - lässt sich durch die unantastbare Verteidigung seiner Verfassung lösen. Die autonome innere Selbstverwaltung der Autonomen Regionen umfasst nicht das Recht auf Selbstbestimmung nach außen; jedoch müssen wir uns der unvernünftigen national-populistischen Herausforderung entgegenstellen, in dem wir die sachliche Unantast- 
barkeit des Verfassungstextes in einer notwendigen Reform des Federalsystems unseres sozialen und demokratischen Staates betonen.

Schlüsselwörter: Verfassungsrecht, Unantastbarkeit der Demokratie, Selbstbestimmung, Populismus, Rechtsstaatlichkeit.

SUMARIO: I. UNIDAD Y NACIÓN(ES): EN DEFENSA DE LA CONSTITUCIÓN.-II. PLURALIDAD TERRITORIAL Y ESTADO DE LAS AUTONOMÍAS: AUTOGOBIERNO (INTERNO) VS. AUTODETERMINACIÓN (EXTERNA).-III. CONTRA LA SINRAZÓN POPULISTA E INDEPENDENTISTA: CLÁUSULA DE INTANGIBILIDAD Y REVISIÓN FEDERAL DEL ESTADO DEMOCRÁTICO.

«A legally unrestricted majority rule, that is, a democracy without a constitution, can be very formidable in the suppression on the rights of minorities and very effective in the suffocation of dissent without any use of violence. But that does not mean that violence and power are the same» (H. Arendt, On Violence, 1969).

\section{UNIDAD Y NACIÓN(ES): EN DEFENSA DE LA CONSTITUCIÓN}

«For the moment at least, writing the history of nations and states seems much less important than tracing the origins of our world of movement, with its frenetic exchange of goods and ideas, its bybrid cultures and its fluid identities» [John Darwin, After Tamerlane. The Rise E Fall of Global Empires, 1400-2000 (2007)].

En España, a partir de 1978, la autodeterminación popular y la sujeción jurídica se reconducen a la mínima expresión del art. 9.1 de nuestra Constitución. El sujeto colectivo que se dota a sí mismo de Norma Suprema -identificado con el mismo fundamento constitucional— es el poder constituyente «del que emanan los poderes del Estado» ${ }^{1}$. Sin embargo, vigente la Constitución, y dentro del Estado de Derecho en que «se constituye» España (art. 1.1), ese todos (pluralidad de individuos que forman Estado) para una (Nación) transforma los sujetos individuales en objetos del poder, es decir, personas jurídicas en un ordenamiento determinado desde

\footnotetext{
${ }^{1}$ «La Nación» que «en uso de su soberanía, proclama su voluntad» del Preámbulo ; «la indisoluble unidad» del art. 2, y el art. 1.2 de la Constitución Española (CE).
} 
sus valores superiores, pero —en cuanto social y democrático- definidos como ciudadanos con derechos y deberes que participan activamente en los asuntos públicos, mutando el Poder (singular) en poderes (plurales y no reconducibles a los tres del clásico modelo liberal) ${ }^{2}$.

El uno del Poder constituyente se convierte en la pluralidad de los poderes constituidos, y todos ellos - no solo las instituciones, sino también los ciudadanos como actores públicos- estarán sometidos a un orden jurídico (uno para todos) con la Constitución como Norma Fundante en forma (procesos de auto-reproducción normativa) y contenido (valores axiológicos que fundamentan y preceptos materiales que obligan). Desde aquí, y a pesar de una jurisprudencia constitucional mal pensada y en contradicción con la defensa democrática, la legalidad formal de la Constitución (reforma rígida) no destruye su propia supremacía material (definición inviolable e intangible) $)^{3}$.

Pero la deficiente interpretación del Tribunal Constitucional — suprema en cuanto fuente del Derecho- no nos exime de buscar otras hermenéuticas más coherentes con el contexto social europeo, con la defensa de los derechos universales y con la necesidad de dar una respuesta institucional al órdago nacional-populista desde el independentismo catalán. Así, el concepto de nación puede que sea «extraordinariamente proteico» ${ }^{4}$, pero, en cualquier caso, tiene que delimitar sus significados en un Estado constitucional que quiere ser más democrático. De ahí que debamos rechazar esa visión tan estrecha que ancla la forma «Estado» en la identificación exclusiva y excluyente con una Nación y su derecho ilimitado de autodeterminación. La complejidad del presente español no se puede reconducir desde el anacronismo decimonónico de un Estado-nación homogéneo como

${ }^{2}$ Libertad, justicia, igualdad y pluralismo político del art. 1.1; art. 23 CE; múltiples poderes públicos, horizontales y territoriales, tal y como demuestra la propia estructuración constitucional en sus Títulos.

${ }^{3}$ Las preguntas originales de la filosofía jurídica - a saber: ¿qué es el Derecho y cuál es su relación con la morallética? (D. Dyzenhaus y M. THORBuRn, Philosophical Foundations of Constitutional Law, Oxford, Oxford University press, 2016, pp. 1-6) - siguen acaparando los focos de un Derecho constitucional que solo se identifica como democrático. Pero, a pesar de los positivistas de la forma y de la reiterada jurisprudencia constitucional sobre la reforma - procedimental e ilimitada modificación de la Constitución («no existe un núcleo normativo inaccesible a los procedimiento de reforma constitucional» [sic] STC 103/2008, de 11 de septiembre, FJ 4, que declaró inconstitucional la Ley del parlamento vasco sobre consultas populares)—, sin sujeción a una mínima cláusula de intangibilidad, tal y como recoge implícitamente nuestro art. 10.1 CE, podrá —-formalmente— revisarse la Constitución, pero el Estado democrático tendría los días contados.

${ }_{4}^{4}$ De la polémica STC 31/2010, de 28 de junio, FJ 12, sobre el Estatuto de Cataluña. 
única normalidad política, donde cualquier pluralidad nacional es descrita como enfermiza y necesitada de tratamiento quirúrgico o, en el mejor de los casos, como constitucionalmente irrelevante. El viejo maniqueísmo entre buenos y malos nacionalismos, verdaderas e inventadas naciones, hace tiempo que mostró sus muchas vergüenzas frente a identidades yuxtapuestas, sus proyectos de integración política y los valores inherentes de la democracia constitucional.

Desdeñando la deriva excluyente de la supuesta identidad nacional entre gobernantes y gobernados, y más aún su realización representativa por el líder — como lucha existencial— del Schmitt más peligroso ${ }^{5}$, el problema de la unidad democrática en la pluralidad política y territorial que encara la Constitución española ${ }^{6}$, se resuelve fortaleciendo un orden federalizado e integrado en Europa y en el mundo:

A) Unidad nacional/popular v. pluralidad de ciudadanos y poderes públicos. La antinomia uno/muchos como distinción entre Poder constituyente y poderes constituidos se disuelve en la conversión constitucional de ese Pueblo-Nación, como uno (sujeto colectivo con voluntad propia, «exclusiva e indivisible» ${ }^{7}$ ) en la pluralidad ${ }^{8}$ (por un lado, los ciudadanos y sus derechos políticos; por otro, la distribución horizontal y territorial de los poderes del Estado; y, en ambos lados — sean ciudadanos, sean poderes públicos de todo tipo y ámbito territorial— su sujeción a la Constitu-

5 Amigos (los nuestros: de la Nación sublimada) contra enemigos (los otros: sean de fuera, extranjeros; o haya que asimilar y/o eliminar a la fuerza, minorías nacionales y cualquier grupo o individuos que disputen la identidad colectiva mayoritaria). Vid. J. A. SANZ MORENO, «El parlamentarismo en su encrucijada: Schmitt versus Kelsen, o la reivindicación del valor de la democracia», Revista de Estudios Políticos, núm. 162 (2013), pp. 118-128.

${ }^{6}$ «En el Estado constitucional, el principio democrático no puede desvincularse de la primacía incondicional de la Constitución que, como afirmó este Tribunal en la STC 42/2014, FJ 4.c), «requiere que toda decisión del poder quede, sin excepción, sujeta a la Constitución, sin que existan, para el poder público, espacios libres de la Constitución o ámbitos de inmunidad frente a ella»» (STC 259/2015, de 2 de diciembre, FJ 4).

7 «(E)n el actual ordenamiento constitucional solo el pueblo español es soberano, y lo es de manera exclusiva e indivisible, a ningún otro sujeto u órgano del Estado o a ninguna fracción de ese pueblo puede un poder público atribuirle la cualidad de soberano» (STC 42/2014, de 25 de marzo, FJ 3).

8 «Por lo que respecta a su contenido, resulta que entre los valores superiores que la Constitución propugna se encuentra el del pluralismo político, pieza cardinal de nuestro orden de convivencia. Lo que caracteriza a la democracia es la continua toma de decisiones y la apertura a todas aquellas posibilidades que fueron desestimadas en el pasado por cualesquiera razones. Todo ello proporciona capacidad evolutiva al constitucionalismo pluralista propio de nuestro Estado social y democrático de Derecho» (ATC 24/2017, de 14 de febrero, FJ 8). 
ción y al resto del ordenamiento jurídico, desde el respeto a la ley y a los derechos de los demás, arts. 9.1 y 10.1), y con una actuación estatal ${ }^{9}$ que también se proyecta internacionalmente ${ }^{10}$.

B) Unidad territorial v. pluralidad autonómica. El ambivalente consenso entre el fundamento de la propia Constitución («unidad de la Nación española») y el reconocimiento del «derecho a la autonomía de nacionalidades y regiones» se reconduce con el autogobierno autonómico de la organización territorial del Estado (autodeterminación interna del Estado de las Autonomías de los arts. 2 y 137) y a través del desarrollo de un principio dispositivo ${ }^{11}$, también abierto a la subsidiariedad y a la cesión internacional de soberanía ${ }^{12}$.

C) Unidad constitucional v. pluralidad jurídica. La máxima un Estado (España), una única Constitución (1978) y un solo titular de la soberanía (el Pueblo español y su identificación nacional) ${ }^{13}$ - se realiza normativa-

9 Con el Rey, Jefe del Estado, como símbolo de esa unidad (Art. 56.1 CE) y, de ahí, su participación en las actuaciones estatales más importantes de los poderes públicos y órganos constitucionales.

${ }_{10}$ Arts. 10.2 y $93-96$.

${ }^{11}$ Sus diferentes procesos de plasmación: arts. 143 y ss.

12 Art. 93.

13 «En el Estado social y democrático de Derecho configurado por la Constitución de 1978 no cabe contraponer legitimidad democrática y legalidad constitucional en detrimento de la segunda: [...] En una concepción democrática del poder no hay más legitimidad que la fundada en la Constitución» (STC 259/2015, de 2 de diciembre, FJ 5). Desde una articulación democrática del Estado constitucional no cabe ejercicio relevante del poder fuera de las manifestaciones recogidas en el texto constitucional, pero reducir la legitimidad democrática a la legalidad constitucional confunde el fundamento de esa legalidad con la legalidad misma. O, peor, se identifica con la legitimidad: «En definitiva, solo en el respeto a los procedimientos legislativos es constitucional y, por tanto, legítima la voluntad de la Cámara» (STC124/2017, de 8 de noviembre, FJ 6). Sin embargo, superando la ficción de la pureza kelseniana (legitimidad $=$ legalidad y Estado $=$ Derecho, con el vacío material $-o$ redundan te- de considerar todo Estado como de Derecho), y en buena argumentación jurídico-política, estamos ante dos conceptos diferenciados y diferenciables: de un lado, la legitimidad democrática de la Constitución, como obra del Poder constituyente (Preámbulo, y arts. 1.2 y 2); y, de otro, la legalidad constitucional o principio de constitucionalidad, como sometimiento de ciudadanos y poderes públicos a la Constitución y al resto del ordenamiento jurídico (Art. 9.1 CE). La legitimidad quiere conocer el quién (pueblo, nación, soberano, poder constituyente, en su identificación constitucional); la legalidad y la constitucionalidad determinan el cómo y porqué de la validez de las normas con la Constitución como cúspide normativa. La doctrina de las dos caras, tan querida por Norberto Bobbio, sale - de nuevoa nuestro encuentro: de un lado, la política, con la soberanía y su comprensión democrática desde el poder del pueblo, «concebido como unidad ideal de imputación del poder constituyente»; de otro, lo jurídico, con la Constitución como Norma fundamental y fundamentadora del derecho, que se clarifica en la «sumisión a la Constitución de todos los poderes públicos (art. 9.1 CE)», lo que se deriva en «el cualificado deber de acatamiento a la Constitución que recae sobre los titulares y cargos públicos, incluidos los electos, "que no se cifra 
mente con la conversión ciudadana en personas jurídicas con obligaciones y derechos que cuentan con unos poderes públicos sometidos a la ordenación e integrados en «un sistema de valores y principios de alcance universal» que defiende la dignidad humana ${ }^{14}$. El contenido inviolable y la cláusula de apertura de los apartados 1 y 2 del art. 10 refuerzan una integración jurídica con los derechos constitucionales en cuanto fundamentos esenciales de un orden, democrático y social, vinculado - en su pluralismo internacionalista - a la protección universal de los derechos humanos ${ }^{15}$.

A pesar la retórica absolutista sobre la soberanía nacional, en el Estado democrático ha desaparecido toda totalización del poder bajo los valores intangibles insertos en la Constitución ${ }^{16}$. De ahí la debilidad de una juris-

en una necesaria adhesión ideológica a su total contenido, pero sí en el compromiso de realizar sus funciones de acuerdo con ella y en el respeto al resto del ordenamiento jurídico" (en tal sentido, entre otras, SSTC 101/1983, de 18 de noviembre, FJ 3, y 122/1983, de 16 de diciembre, FJ 5)» (ATC 24/2017, de 14 de febrero, FJ 9). Y, precisamente, la fusión de ambas caras es la que nos permitirá ver la moneda completa de la democracia constitucional: rechazando la visión schmittiana del Poder constituyente como omnipotente e ilimitado, tan exaltada por los nuevos populismos, y, al tiempo, prescindiendo de la Grundnorm de KELSEN, pero también de la Constitución jurídico-positiva como principio y fin del derecho, superaremos el concepto absoluto de soberanía popular con la Constitución como límite al poder en una democracia que, o se define como intangible o, más pronto que tarde, desaparecerá.

${ }_{14}$ STC 21/1981, de 15 de junio, FJ 10.

15 Nos lo recuerda FerRAJOLI: «el pueblo, aunque como sujeto colectivo ejerce el poder a través del principio de mayoría, su capacidad volitiva no le permite decidir sobre lo que no le pertenece; en concreto, la supresión o restricción de los preceptos constitucionales que establecen los derechos fundamentales no puede ser objeto de decisión popular» (L. FERRAJoli, Principia iuris. Teoría del derecho y de la democracia. 2. Teoría de la democracia, Madrid, Trotta, 2011, pp. 12-13).

${ }^{16}$ El TC expone demasiadas veces esa dialéctica totalizante del poder soberano del Pueblo/Nación; un ejemplo: «... aseguramiento de que los gobernantes sean servidores, no señores, de las leyes, y muy en primer lugar de la Constitución y de las normas que en ella disciplinan los procedimientos para su propia e ilimitada revisión formal» STC 114/2017, 17 octubre, FJ 5; verbalizando nada menos que una revisión sin límites de la Constitución («d) Llegado aquí, hemos de recordar una vez más que todos los preceptos de la Constitución son susceptibles de reconsideración y revisión en Derecho, [...], ya que admite y regula una revisión total»), tan incompatible con el Estado constitucional como su constante apelación a que nuestra democracia no es militante; o, todavía de manera más destructiva para la defensa de la democracia, afirmando que «(En) efecto, la Constitución depara la más amplia libertad para la exposición y defensa públicas, dentro o fuera de las instituciones, de cualesquiera concepciones ideológicas» (sic) (STC 124/2017, de 8 de noviembre, FJ 5). Pero, también aquí, FERRAJOLI, citando incluso el art. 1 de la Constitución española, nos ayuda a repensar la relación entre pueblo, poder y democracia: la soberanía popular, identificada como potestas legibus soluta, arrastra una contradicción irresoluble con la democracia constitucional y con la misma idea de democracia. Sin embargo, la soberanía popular pertenece al conjunto de todas las personas que integran el pueblo, es decir, todos los ciudadanos tendrían su parte alícuota de soberanía, los fragmentos de soberanía popular correspondien- 
prudencia constitucional que, al tiempo que parece demandar una fundamentación material («siempre y cuando no se defienda a través de una actividad que vulnere los principios democráticos o los derechos fundamentales», STC 48/2003, de 12 de marzo, FJ 7), remacha la más extrema de las concepciones procedimentales («no hay límites materiales a la revisión constitucional», STC 103/2008, de 11 de septiembre, FJ 4). Pero, por más que lo reitere el TC una y otra vez ${ }^{17}$, la conversión del titular de la soberanía en ciudadanía política ${ }^{18}$ nunca podrá significar un poder ilimitado no sometido a ninguna cláusula intangible ${ }^{19}$.

Desde aquí, la Declaración Universal de Derechos Humanos de 1948 y los Tratados y acuerdos internacionales sobre las mismas materias ratificados por España no son únicamente el marco de interpretación de los derechos fundamentales, sino «llaves» de inserción del modelo español en una ordenación internacional imposible de soslayar. En este sentido, el ius cogens sería ese ius preceptivum internacional que integra una protec-

tes a cada ciudadana/o (op. cit., pp. 13-18). De ahí que toda violación de derechos no sea una lesión meramente subjetiva, sino también de la propia soberanía popular. El derecho no implica necesariamente democracia; pero la democracia implica necesariamente derecho; o lo que es lo mismo: puede haber derecho sin democracia, pero no democracia sin derecho. La democracia entendida como conjunto de reglas sobre el válido ejercicio del poder: por un lado, reglas que confieren poderes de autodeterminación individual y colectiva, garantizando su igual titularidad a todos, en cuanto personas o ciudadanos; por el otro, reglas que imponen límites y vínculos a estos mismos poderes para impedir su degeneración en formas despóticas y garantizar su ejercicio y la tutela de los intereses de todos.

17 «(S)ólo los ciudadanos, actuando necesariamente al final del proceso de reforma, pueden disponer del poder supremo, esto es, del poder de modificar sin límites la propia Constitución» (STC 103/2008, de 11 de septiembre, FJ 2). «En suma, la Constitución como ley superior no pretende para sí la condición de lexperpetua. Todas y cada una de las determinaciones constitucionales son susceptibles de modificación, "siempre y cuando ello no se prepare o defienda a través de una actividad que vulnere los principios democráticos, los derechos fundamentales o el resto de los mandatos constitucionales"; o, dicho de otro modo, siempre que "se realice en el marco de los procedimientos de reforma de la Constitución, pues el respeto a estos procedimientos es, siempre y en todo caso, inexcusable" (SSTC 138/2015, FJ 4, y 259/2015, FJ 7)» (ATC, 24/2017, de 14 de febrero, FJ 8). Y es, precisamente, esa concepción tan positivista y formal como vacía — defendida tan reiteradamente por la jurisprudencia del TC como para convertirse en canon desde la académica- lo que repudiamos en nuestra comprensión del orden constitucional y democrático como intangible.

${ }^{18}$ El Pueblo, identificado con la Nación española, pero en su ejercicio por los titulares del derecho fundamental a participan en los asuntos públicos (arts. 1.2 y 2 en su conversión democrática desde el art. $23 \mathrm{CE}$ ).

19 «La dignidad de la persona y los derechos inviolables que le son inherentes» son «fundamento del orden político y de la paz social» (art. 10.1) y, por tanto, límites intangibles —en su versión más minimalista — de una democracia constitucional que, desde la (re) forma, no puede promover un vacío axiológico y valorativo que ponga en peligro su propia pervivencia. 
ción universal de derechos humanos como valores inquebrantables que se imponen a la tan cacareada omnipotencia estatal ${ }^{20}$.

La interacción entre la salvaguarda de los derechos inviolables y la sujeción de ciudadanos y poderes públicos al ordenamiento constitucional nos protegen de toda decisión ilimitada en manos del titular soberano y su ejercicio procedimental a través de la tiranía de la mayoría. Ninguna interpretación constitucional puede olvidar que el Estado y su poder soberano - con la transformación del fundamento de la Constitución (la Nación) y del titular de la soberanía nacional (el pueblo español) en ciudadanos que participan en los asuntos públicos, directamente o por medio de representantes (arts. 2, 1.2 y 23) — no crean derecho de la nada, aislados en su estatalismo cerrado al mundo.

La inmersión del sistema constitucional en órdenes europeos e internacionales de protección de derechos no debe obviarse a la hora de definir la soberanía y el poder de reforma constitucional. El Pueblo/Nación, en cuanto titular originario del poder, ya ha quedado constituido y solo se podrá expresar a través de los cauces prescritos en su propia decisión constituyente, pero atendiendo a su lugar dentro de la Comunidad Internacional. Con la Constitución, la misma adjetivación del Estado de Derecho como social y democrático (art. 1.1), nos confirma no solo las reglas del procedimiento jurídico (democracia formal), sino una fundamentación en valores y fines universales (democracia material y teleológica), que, desde sus distintas perspectivas, dan sentido y proyección dinámica a todo el ordenamiento: de un lado, y como frontera mínima, la dignidad de la persona y sus derechos inviolables; y, de otro, como desarrollo de ese orden político y de su paz social, la promoción de la libertad e igualdad reales y efectivas y la educación democrática de su ciudadanía (arts. 10.1, 9.2 y 27.2 CE).

Por eso conviene recordar que no se puede confundir la definición sustancial de la Constitución con su proceso de cambio. Las enseñanzas del

20 Vid. C. H. ChInKIN, «Sources», en D. MoECKLI (ed.), International Human Rights Law, Oxford, Oxford University Press, 2014, pp. 75-95. El art. 53 de la Convención de Viena de 1969 recoge la noción de ius cogens: normas perentorias de Derecho internacional general, aceptadas y reconocidas por «la comunidad Internacional de Estados en su conjunto» y que «no admite(n) acuerdo(s) en contrario y que solo puede(n) ser modificada(s) por una norma ulterior de Derecho internacional general que tenga el mismo carácter». Esta definición convencional del ius cogens supone una limitación definitiva a la capacidad estatal de negociar con otros sujetos de Derecho internacional, al constatar como «nulo todo tratado que, en su momento de celebración, esté en oposición con una norma imperativa de Derecho internacional general» (del mismo art. 53). 
mejor Schmitt ya nos lo confirmaron: destrucción y supresión de la Constitución no se identifican con su defensa a través de la reforma ${ }^{21}$. Pero que «la Constitución no constituya un texto jurídico intangible e inmutable» ${ }^{22}$ no significa que la propia democracia sobreviva sin su intangibilidad. El formalismo vacío de contenido que destila buena parte de la jurisprudencia constitucional deja de ser garante y se ha convertido en el inesperado embrollo al que habrá que dar una respuesta desde un Estado constitucional y democrático que merezca tal nombre.

En el choque entre valores universales e ideología ontológica, el TC parece renunciar a límites infranqueables desde la sublimación nacional del titular del poder con una forma de ejercicio meramente procedimental. Pero el valor de la Constitución democrática ni se reduce a la introducción de técnicas normativas para el ejercicio del poder, ni se reconduce como poder constituido en funciones constituyentes no sometido a más límites que los procedimentales de revisión/reforma. La superlegalidad formal se completa con una definición material que presenta el mecanismo de reforma y el propio modelo de justicia constitucional como los instrumentos supremos para su defensa. En cambio, si por el procedimiento de reforma muta toda la Constitución o aparecen nuevos sujetos constituyentes, serviría no ya para su garantía, sino para la ruptura más radical: una ciudadanía nacionalizada, no sujeta a ningún límite, estaría legitimada para emprender el camino hacia la propia desmembración de sus derechos colectivos o, peor aún, hacia la superación de los derechos humanos e individuales ${ }^{23}$. Por tanto, debemos impugnar el despotismo poco ilustrado de formulaciones meramente aritméticas: el principio democrático del gobierno de la mayoría no puede llevarnos al absurdo del simple recuento de votos, y no por-

${ }^{21}$ «Whether Schmitt is correct that fundamental constitutional change or replacement can happen only after some kind of revolution and the abrogation of the existing constitutional order is open to dispute. Hans Kelsen, for example, disagreed with Schmitt and thought that an entire constitution could be replaced by the ordinary amendment procedure» (R. STACEY, «Popular Sovereignty and Revolutionary Constitution-Making», en D. DyzENHAus y M. Thorburn, Philosophical Foundations..., op. cit., p. 168). Sin embargo, ya va siendo hora de cerrar definitivamente esta disputa: ni aceptamos el poder constituyente ilimitado de SchmitT, ni la revisión total de la Constitución de KeLSEN, si con ello caemos en una construcción tan formal que dejara sin defensas la democracia constitucional frente a sus enemigos. Y, por ello, compartimos la conclusión de STACEY de una soberanía popular limitada: «My position is rather than the claim to popular sovereignty imposes substantive limitations on constitution-making [...] against both unbounded popular sovereinty and majoritarian democrats who accept without question what the majority decides» (ibid., p. 178).

${ }_{22}$ ATC 24/2017, de 14 de febrero, FJ 8.

${ }_{23}$ T. van Boven, «Categories of Rights», en D. MoEcKLI (ed.), International Human Rights Law, op. cit., pp. 145-147. 
que el pueblo se equivoque —algo no descartable — sino porque — demasiadas veces- también puede ser engañado.

Es imprescindible elegir entre la Constitución como límite al poder o la omnipotencia de este, y aquí no caben malabares equilibristas - apegados a una estrecha literalidad constitucional—, como los propugnados, de manera arcaizante, por su Supremo Interprete, que olvida hermenéuticas más actuales y fundamentadas, en cuanto sociológicas y sistemáticas, con la integración internacional del orden español. La democracia, o se concibe como sustancial y prescriptiva, o caemos en la mera descripción de un procedimiento tan formal y matemático como devastador y suicida. La titularidad de la soberanía y el ejercicio del poder, o bien se definen desde la libertad individual, el pluralismo político, y los derechos de participación ciudadana en los asuntos públicos ${ }^{24}$, o acaban subsumidos en una democracia de identidad con la inmersión de cada individuo dentro de una presupuesta Nación como sujeto todopoderoso, vivo y volitivo ${ }^{25}$. Pero la pompa constitucional de su fundamento ontológico en la Nación española no deviene en una ciudadanía numérica sin límite alguno a su actuación política. El principio de protección contra la tiranía de la mayoría es tan consustancial a la democracia que, con su desaparición, se cercenaría toda posibilidad de una definición sustantiva a manos del más puro formalismo colectivo. De ahí la necesidad de abandonar todo lenguaje existencial de un ser político unificado descrito como total e ilimitado ${ }^{26}$.

La legitimad democrática, en cuando reclamación de «la mayor identidad posible entre gobernantes y gobernados», desde una perspectiva estatal, descansa en una voluntad popular que — «en su veste de poder constituyente»— podrá definirse como «fuente de toda legitimidad jurídico-política» ${ }^{27}$. Pero de ahí inferir que, desde una perspectiva constitucional, el pueblo de Cataluña y también el conjunto del pueblo español

${ }^{24}$ Autodeterminación desde el individuo y su proyección colectiva en una democracia sustantiva y finalista (arts. 1.1., 6, 9.2, 10.1 y 23).

${ }_{25}$ Autodeterminación nacional, desde una construcción absoluta no sujeta a ningún límite (Preámbulo, arts. 2, 8.2, 13.2 o 14, e interpretación aislada del art. 168, sin su propia contextualización con otros preceptos y desdeñando su significado como mecanismo de defensa), en su reencarnación nacional-populista y/o independentista.

${ }_{26}$ Reducir la legitimidad democrática a su cierre exclusivo en un Estado-nación que, desde el origen popular del poder, delimita su ejercicio bajo la regla de la mayoría, se resuelve como la pretensión de prevalencia de las decisiones que cuenten con la cobertura ciudadana del mayor número de votos (D. Held, Models of Democracy, 3. ${ }^{a}$ ed., Cambridge, Polity Press 2006, p. 291).

27 STC 42/2014, de 25 de marzo, FJ 4, sobre la Declaración de soberanía y del derecho a decidir del pueblo de Cataluña. 
sean sujetos que se constituyen jurídicamente en virtud del reconocimiento recogido en la Constitución, dibuja un universo normativo que no solo obvia la realidad socio-histórica y el propio fundamento nacional preexistente a la Constitución, sino que se asienta en una «unidad ideal de imputación del poder constituyente» tan supuesta como ficticia era la Grundnorm kelseniana, desdibujando nuestro lugar en el mundo y perpetuando una definición moribunda del derecho tan monista estatalmente como ajena a los nuevos nomos de alcance universal ${ }^{28}$.

La legitimidad democrática del modelo constitucional español precisa reencontrarse con la ciudadanía y lo hace desde su mejor comprensión histórica y con proyección de futuro: de un lado, su fundamentación pasa$d a$, el referéndum que tuvo lugar el 6 de diciembre de 1978 y, en positivo, los votos a favor que ratificaron la Constitución (sobre el 59 por 100 de un porcentaje electoral del 88 por 100); de otro, su actualización permanente y, en su caso, su modificación, es decir, desarrollo y reinterpretación constante del texto constitucional por ciudadanos y poderes y, en última instancia, por su supremo hermeneuta, con la posibilidad de reforma/revisión de sus preceptos a través de los procesos recogidos en el Título $\mathrm{X}^{29}$.

Sin embargo, la triple legitimidad de nuestro Estado constitucional ${ }^{30}$ (pasada, referéndum constituyente; presente, validez constitucional y apli-

${ }^{28}$ Mantener que «"desde un punto vista jurídico-constitucional, el 'pueblo de Cataluña' [...] integra, sin embargo, un sujeto que se constituye en el mundo jurídico en virtud del reconocimiento constitucional (al igual que sucede con el conjunto del 'pueblo español' [...]” (STC 42/2014, FJ 3)» (STC 114/2017, 17 octubre de 2017, FJ 5), expone un positivismo tan fuera de la historia como ajeno a toda definición del derecho como hecho por y para individuos de carne y hueso, en el que la fundamentación de la Constitución (art. 2) se resuelve sobre su base en la dignidad humana (art. 10.1).

${ }^{29}$ Cabe, no obstante, constatar sus imperfecciones técnicas y la necesaria superación de las mismas cuando se aborde — de manera coherente— la futura reforma/revisión: no inclusión de iniciativa popular para la reforma constitucional (cercenando la visión de la ciudadanía en su legitimación constituyente); posibilidad de modificación por el procedimiento agravado ordinario con referéndum meramente facultativo (reforma de la Constitución sin ratificación popular); deficiente inserción de preceptos sujetos al sistema super-agravado y su apelación a la revisión total (inclusión de todo el Título II De la Corona, cuando ya aparece la Monarquía en el art. 1.3, olvido de la referencia al art. 10, etc.); en definitiva, confusión en su articulación como instrumento de defensa y, por encima de todo, la ausencia de una cláusula explícita de intangibilidad que ha permitido una jurisprudencia constitucional tan alejada de nuestro entorno como contradictoria con la salvaguarda de la democracia constitucional.

${ }^{30}$ Para BARnARD, la legitimidad envolvería, al menos, tres perspectivas: Derecho constitucional/electoral a gobernar; la validez normativa/procedimental para el ejercicio del poder; la concreción teleológica/sustantiva de los fines de ese gobierno (F. M. BARNARD, Democratic Legitimacy. Plural Values and Political Power, Montreal, McGill-Queen's University Press, 2001, p. 26). Pero la legitimidad democrática no puede convertirse en una mera 
cación y desarrollo de sus preceptos; y, permanente o futura, la reforma/ revisión constitucional) quedaría en mera democratización formal si no subrayamos el propio soporte del fundamento de la Constitución: la naturaleza objetiva de los derechos fundamentales como base fundante de la unidad nacional. La doctrina constitucional más lúcida ya nos lo advertía, al aportarnos una interpretación global de toda la Constitución, con la doble naturaleza en la significación de los derechos fundamentales (subjetiva, status jurídico personal o libertad; y objetiva, base material del orden jurídico). Por eso los derechos, con su vinculación directa entre individuos y Estado, «actúan como fundamento de la unidad política sin mediación alguna ${ }^{31}$.

\section{PLURALIDAD TERRITORIAL Y ESTADO DE LAS AUTONOMÍAS: AUTOGOBIERNO (INTERNO) VS. AUTODETERMINACIÓN (EXTERNA)}

«When Alabama seceded from the Union on 11 January, 1861, Winston County seceded from Alabama, and every child... knew it», (To Kill a Mockingbird, Harper Lee, 1960).

El proceso de federalización que ha vivido España estos últimos cuarenta años para desarrollar la pluralidad territorial de sus «nacionalidades y regiones» y hacer efectivo su derecho a la autonomía ha sido - a pesar de recientes y lacerantes críticas ${ }^{32}$ - tan complejo como contunden-

cuestión de éxito electoral (ibid., 38): la dimensión electoral es necesaria para determinar el gobierno y sus cambios, pero no suficiente; sin otras perspectivas reduce la democracia a su comprensión schumpeteriana como simple lucha por el voto (D. HELD, Models of Democracy, op. cit., p. 477), o, desde el SснмiтT de Legalidad y Legitimidad, a las primas por el ejercicio del poder.

${ }^{31}$ STC 25/1981, de 14 de julio, FJ 5, STC 247/2007, de 12 de diciembre, FJ 13. «La dimensión objetiva...y su carácter de elementos esenciales del ordenamiento» (STC 196/2006, de 3 de julio, FJ 6) definen a los derechos fundamentales como contenido intangible del mismo fundamento constitucional en la unidad de la Nación (art. 2).

32 Pérez Royo habla incluso de «Constitución monárquica, bipartidista y antifederal (sic)» (J. PÉREz Royo, La reforma constitucional inviable, Madrid, Catarata, 2015, p. 107), afirmando que «(u)na Constitución territorial que descansa en la provincia carece de legitimidad democrática. Y al carecer de legitimidad democrática es inservible», para, poco después - y en contradicción flagrante con lo anterior- asegurar lo siguiente: «El binomio Constitución/Estado de las Autonomías en el que ha descansado el Estado de las Autonomías para intentar integrar todas las "nacionalidades y regiones" en un Estado español ha sido operativo durante más de treinta años» (ibid., pp. 134 y 135). Sin legitimidad e inservi- 
te. $\mathrm{Y}$, sin embargo, actualmente, somos conscientes si no de su fracaso al menos de su debilidad en la resolución del objetivo principal por el que se consensuó su anclaje constitucional: la respuesta a identidades territoriales singulares — se llamen nacionales o no- y a los anhelos de autogobierno (autodeterminación interna) de determinadas colectividades territorialmente asentadas ${ }^{33}$.

La crisis económica, la corrupción sistémica y, sobre todo, su impacto en la desafección ciudadana a las instituciones, independientemente de errores políticos, normativos o jurisprudenciales, de uno u otro lado -más o menos magnificados según el portavoz de la narración de los acontecimientos-, han determinado la presente zozobra de un modelo autonómico que tiene que hacer frente ya no al desarrollo de más autogobierno, sino a su deriva directa y unidireccionalmente independentista, reclamando un inexistente derecho de autodeterminación externa o de secesión y, para más burla, dando sin rubor lecciones de qué sea la democracia y quién su titular. Pero, a estas alturas del conflicto, seguir manejando propuestas de reformas almidonadas o la manida transformación del Senado en auténtica Cámara de representación territorial — cuando incluso los nacionalismos vascos y catalanes más proclives a respetar la ordenación jurídica están en otras reivindicaciones (reconocimiento nacional, articulación del supuesto derecho a decidir, bilateralidad, etc.) — no parece que sea ninguna solución medianamente duradera.

Sin embargo, cuando una ruptura absoluta con el Estado se manifiesta unilateralmente ${ }^{34} \mathrm{o}$, al menos, se postula, desde una concepción sesgada de

ble u operativo más de treinta años, ¿con qué nos quedamos? Independientemente de nuestra respuesta, Pérez Royo prosigue su crítica: «El "naufragio" de la reforma del Estatuto de Autonomía de Cataluña como consecuencia de la STC 31/2010 ha supuesto el fin de lo que había operado como Constitución territorial» (ibid., p. 135), abonando la retórica independentista de que todo empezó con la STC, como si — a pesar del disparate histórico que supuso su cerrazón en la definición de nación [«... importa [...] única y exclusivamente la nación en sentido jurídico-constitucional» FJ 12 (sic)], o, peor todavía, llevarlo al fallo- la jurisprudencia constitucional no fuera una más entre tantas equivocaciones de tantas partes (estatales, autonómicas, gubernamentales, legislativas, jurisdiccionales, etc.), con la corrupción, por encima de todas, sobrevolando demasiadas cabezas y partidos.

${ }_{33}$ Vid. S. EsCÁMEZ, «El Estado autonómico: elementos para comprender su crisis y pensar en su relegitimación», en I. Wences, Tomando en serio la Teoría Política, Madrid, Centro de Estudios Políticos y Constitucionales, 2015, pp. 621-642; J. MARTín, El federalismo plurinacional. ¿Fin de viaje para el Estado autonómico? Madrid, Díaz \& Pons, 2014.

34 Aunque se presente, después, el procés como «partida de póker»-en la que los dirigentes iban «de farol», según declaraciones de la exconsellera de educación del Govern de la Generalitat, huida de la justicia, Clara Ponsatí-, la apuesta por la unilateralidad y la ruptura no pueden eludirse. 
la democracia que sublima el ámbito propio de decisión [derecho innegociable y eterno a elegir el futuro político desde la parte (el pueblo, nacionalidad o nación — según se quiera - del territorio autonómico), obviando el todo (la nación o pueblo español en su conversión como conjunto de ciudadanos con derechos políticos)], no queda mucho margen para el diálogo y menos aún para los acuerdos compartidos. Pero, vistas las circunstancias a partir de septiembre de 2017, mantener el referéndum binario — de SÍ/NO a la independencia de Cataluña — como salida resolutoria del problema, significaría no solo repudiar nuestro orden constitucional, sino propiciar la agonía de su mejor comprensión democrática.

Cuando, tal y como muestran las reiteradas elecciones catalanas de los últimos años, la sociedad cuenta con dos mayorías - algo fluctuantes, pero, porcentualmente, más o menos estables- que se decantan casi 50-50 hacia uno u otro lado, pretender someter al pueblo catalán a un referéndum para presentar su voluntad es tanto como asumir que una minoría - contingente, circunstancial y, en todo caso, nunca unificadora socialmente- decante la balanza ${ }^{35}$ - Por esa realidad tan plural y diversa, con identidades — las más de las veces- también múltiples y no solo excluyentes, la propuesta de referéndum polarizador debe entenderse como pantalla superada — de manera dolorosa, para todos, el 1 de octubre- y, para no repetir medias verdades o clamorosas mentiras, conviene no volver a ella y restañar heridas y relatos parciales ${ }^{36}$.

35 El ejemplo del referéndum sobre el Brexit es aquí más que elocuente (participación 72 por 100: dejar la UE, 52 por 100; continuar en la UE, 48 por 100, es decir, de más de 33 millones que votaron, 17 eligieron salir frente a 16 millones que preferían mantenerse en la Unión Europea): Reino Unido partido en mil pedazos, con dualidades múltiples, Escocia $v$. Inglaterra, Londres y grandes ciudades $v$. zonas rurales, jóvenes $v$. viejos, niveles de estudio y cualificación profesional, etcétera, que decide salir de la UE, tras una campaña repleta de fake news, interferencias, etcétera, por un porcentaje irrisorio del electorado que, no obstante, se toma como decisión monolítica de la voluntad popular británica («why?»).

${ }^{36}$ La indiferencia significativa entre plebiscito y referéndum nos lleva a considerar ambos instrumentos como sinónimos y característicos de una democracia participativa directa que traslada o consulta a los votantes cuál debe ser la voluntad estatal. La diferenciación por la cuestión sometida al electorado — de carácter más constitucional, en el referéndum; de menor relevancia política y/o de adhesión expresa a un candidato, para los plebiscitos- es demasiado abierta como para permitir una distinción tan clara como la existente entre Constitución y Ley, e, incluso aquí, habría fronteras más que dudosas. Con todo, lo que es manifiesto es que la votación popular deviene, así, en clave de la mutación de la forma de Estado que ya detectara ScHmiTT con su entrada de los tres legisladores extraordinarios; y, ahora, frente al escoramiento del modelo parlamentario hacia uno gubernamental, con la prelación presidencialista y su capacidad legislativa - en concreto, como legislador extraordinario, por razón de la necesidad-, la clave estaría, con la demanda de empoderamiento a la ciuda- 
No obstante, si se quiere mirar de frente al soberanismo, la posibilidad de plantear la revisión de la Constitución para establecer un procedimiento bien definido que resolviera el choque entre el orden democrático y los deseos de independencia expresados por las minorías nacionales, se presenta como una solución transaccional que pudiera contar con el asentimiento de aquellos que ya no se conforman con mayores cotas de autogobierno interno, y cuya única salida definitiva es la autodeterminación externa que conduzca a la independencia, pero que, no obstante, proclaman, al menos, su respeto y acatamiento ante una respuesta diferente, siempre que cuente con mayor respaldo popular.

Desde un punto de vista estrictamente democrático, cuando una gran mayoría, dentro de una minoría autonómica que ha espoleado su construcción nacional, no desea mantener los vínculos de unión con el Estado, no parece razonable dejar únicamente al conjunto de la ciudadanía estatal toda la decisión y obviar la tensión entre mayorías de los diferentes ámbitos de ordenación territorial. En este sentido, ya sabemos que la resolución al problema de la ausencia de derecho a declarar la independencia de forma unilateral que formulara el Tribunal Supremo de Canadá, con su Opinión sobre el caso de Quebec en 1998, fue ejemplarizante: claridad de la pregunta, claridad de la respuesta a favor de la secesión y, en todo caso, posterior negociación entre las partes (instituciones centrales y poderes territoriales). Así lo ha reconocido - aunque de forma algo parcial y oscura- la STC 42/2014, de 25 de marzo: se rechazaba «la adecuación de un proyecto unilateral de secesión» (FJ 3), pero también se admitía -lo que no menciona la sentencia, tal y como recuerda Fossas ${ }^{37}$ — que los propios principios constitucionales y la legitimidad democrática eran fundamentos suficientes para establecer el procedimiento legal admisible. Por tanto, y ante la pregunta de Norman — «¿es democrática la secesión?»38 — la única

danía y las envestidas populistas de diferentes espectros políticos, en la reconstrucción de la democracia, adjetivada como representativa, en democracia directa, de referéndums, o plebiscitaria: el llamado schmittianamente legislador extraordinario ratione supremitatis (desde la legalidad, el referéndum catalán sobre el Estatuto de Autonomía y su santificación nacionalista tras la STC 31/2010, y, desde la confrontación con el Estado de Derecho, los intentos unilaterales de consulta/referéndum desde el independentismo, son ejemplos más que significativos del papel del pueblo como poder directo y legitimador — para los rupturistas- de actuaciones excepcionales fuera del marco constitucional).

37 E. Fossas, «Interpretar la política. Comentario a la STC 42/2014, de 25 de marzo, sobre la Declaración de soberanía y el derecho a decidir del pueblo de Cataluña», Revista Española de Derecho constitucional, núm. 101 (2014), pp. 273-300.

38 W. Norman, «Secesión y Democracia (Constitucional)», en F. ReQuejo (coord.), Democracia y pluralismo nacional, Ariel, Barcelona, 2002, p. 89. 
respuesta, agotada la vía del Derecho internacional ${ }^{39}$, nos la proporciona el Estado constitucional de Derecho.

La democracia, en cuanto gobierno del pueblo, parte de la preexistencia misma de ese pueblo: titular ya dado del poder y con capacidad de ejercerlo. El pueblo, con la Constitución, ya está construido y bien podrá cambiar o revisar su propia ordenación y derecho, pero, si quiere mantener su definición como orden democrático, hay que respetar la determinación de su unidad nacional desde su garantía de los derechos fundamentales y su integración en una ordenación internacional que también los ampara y protege. Y, precisamente, la secesión quiebra con esta presuposición de una concepción popular, viva y volitiva, cuestionando la propia democracia como gobierno del pueblo al negar a ese mismo pueblo - en su conjunto- la capacidad de ser y obrar, para plasmar otra preexistencia aún por demostrar, en cuanto titular colectivo parcial que pretende desgajarse de la unión ciudadana hasta entonces definitoria del gobierno democrático $^{40}$. De ahí que la vinculación entre democracia y secesión, de entra$\mathrm{da}$, no funcione, cuando la primera se define procedimentalmente desde el principio de mayoría y la segunda desde la simple autodeterminación de los pueblos, dando o prometiendo a uno, lo que enajena a otro, sea el pueblo parte o sea el pueblo todo ${ }^{41}$.

39 J. A. SANZ MoREno, «Identidades nacionales y ciudadanía en la ordenación autonómica del Estado: democracia formal, autodeterminación y cláusula de secesión», en A. López-Basaguren y L. Escajedo, Los Caminos del Federalismo y los Horizontes del Estado Autonómico, Euskadi, Gobierno vasco, 2012, pp. 1441-1456; ÍD., «Democratic Citizenship and Spanish Multinational (Dis)Order: Procedural Democracy Versus Secession Clause», en A. López-BASAguren y L. Escajedo, The Ways of Federalism, 2, New York, Springer, 2013, pp. 733-741.

40 Conviene recordar, con Norman, lo siguiente: «Es erróneo equiparar la democracia con el gobierno de la mayoría, o dar por sentado que el gobierno de la mayoría prevalece automáticamente sobre otros valores y derechos fundamentales en una democracia liberal» [W. Norman, «Secesión y Democracia (Constitucional)», op. cit., p. 90].

${ }^{41}$ La otra pregunta que formuló NORMAN sigue sin respuesta definitiva: «¿s apropiado que exista una cláusula de secesión en la constitución de un Estado democrático?» (ibid., p. 91; W. Norman, «Teoria federalista de la secessió», en F. REQuejo y M. CAMINAL, Liberalisme polític $i$ democràcies plurinacionals, Catalunya, Generalitat de Catalunya, 2009, pp. $285-$ 362). Porque constitucionalizar la secesión proporcionaría argumentos enfrentados: en contra y a favor. En contra estarían la práctica totalidad de los Estados, que no reconocen en sus textos constitucionales el derecho de secesión, en apoyo expreso a su propio derecho de autodefensa y de integridad territorial. A favor, el ejemplo histórico de Quebec confirma, según NORMAN, las deficiencias que soporta un orden constitucional cuando no recoge expresamente una cláusula de secesión (W. Norman, Negotiating Nationalism, Oxford-New York, Oxford University Press, 2006, pp. 192-203), o como, más que debilitarse, pueden llegar a fortacerse los movimientos independentistas. Sin embargo, la cláusula de secesión no debe confundirse con ningún supuesto derecho de secesión, sino con un simple compro- 
Pero que no funcione de entrada ¿resuelve su vinculación de salida? $\mathrm{Y}$ aquí es donde el Tribunal Supremo canadiense se vino arriba ${ }^{42}$. Ahora, sin embargo, no se trata ya de seguir punto por punto sus recomendaciones: la claridad en la respuesta siempre hará más democrática la decisión, pero plantear también la claridad en la pregunta —el todo o nada ante la independencia - es asumir que la voluntad popular tiene que ser blanco o negro, olvidando su pluralidad y, por tanto, los múltiples colores que puede tener el interés general.

Desde aquí cabe estudiar otras vías más imbricadas que puedan perseguir una mayor autodeterminación interna, sin quebrar la integración con el Estado. Pero debemos comenzar por la batalla por el lenguaje ${ }^{43}$. En tiempos de desafección ciudadana y de explosión de populismos a nivel europeo y mundial ${ }^{44}$, no se puede dejar el eslogan imbatible del derecho a decidir o del derecho de autodeterminación a los que buscan destruir el orden constitucional ${ }^{45}$. España reconoce el derecho a la libre determinación de los pueblos por su ratificación del orden internacional que lo prescribe; por tanto, también las nacionalidades y regiones, que gozan de autonomía para la gestión de sus intereses y conforman la organización territorial del Estado, practican ese derecho de autodeterminación

miso que integra posturas antagónicas en una revisión constitucional que busca determinar nuevas reglas de juego compartidas incluso con los que quieren un fuera, aun estando todavía dentro. No estamos ante ningún derecho democrático, sino ante la posible constitucionalización de un procedimiento para la actualización del marco a seguir, con la transacción entre distintas mayorías con diferente alcance territorial, copartícipes en la determinación de una soberanía conjunta, pero que se sabe compartida y que, sin embargo, no renuncia a encauzar sus desafíos independentistas. Que la cláusula de secesión incentive estos movimientos o, en cambio, que su inclusión constitucional con un procedimiento específico que establezca la necesidad de mayorías calificadas o cualquier otra barrera singular sea un instrumento para desincentivarlos, dependerá — según NORMAN — del Estado concreto y sus singularidades [W. Norman, «Secesión y Democracia (Constitucional)», op. cit., p. 94; ÍD., «Teoria federalista de la secessió», op. cit., pp. 285-362].

${ }_{42}$ Como es sabido, el Tribunal Supremo de Canadá, al encauzar un procedimiento constitucional cuando el propio texto callaba, partía, en todo caso, de un concepto de democracia indisolublemente unido al rule of law; así la secesión unilateral violaría los cuatros principios fundamentales y organizativos de la Constitución: federalismo, democracia, constitucionalismo y Estado de Derecho, y respeto de las minorías.

${ }^{43}$ «En el mundo político, el lenguaje siempre es propiedad del enemigo» (C. FERNÁNDEZ Liria, En Defensa del Populismo, Madrid, Catarata, 2016, p. 36).

44 Vid. J. B. Judis, The Populist Explosion, New York, Columbia Global Reports, 2016.

${ }^{45}$ La propia Declaración Universal de Derechos Humanos de las Naciones Unidas (1948) y los Pactos de 1966 proclaman que todo pueblo está investido del derecho de libre determinación, obligando a cada discurso político a presentar sus credenciales desde su legitimación en un pueblo singularizado. Vid. K. KNOP, Diversity and Self-Determination in International Law, Cambridge-New York, Cambridge University Press, 2002. 
en su vertiente interna y, en consecuencia, se debe hacer pedagogía ciudadana para trasladar esta realidad política y jurídica ${ }^{46}$. Y, si de lo que estamos hablando es del derecho a la autodeterminación externa, es decir, de la unilateralidad de la secesión, es de sobra conocido que no existe ningún país occidental que recoja esta quiebra del derecho estatal de auto-conservación ${ }^{47}$. No obstante, cuando el problema se enquista, no cabe mirar para otro lado: y, desde el Estado constitucional, si ya no basta con legislar o con la aplicación de la legalidad ${ }^{48}$, habrá que plantear su reforma y reforzar — de nuevo — una constitucionalidad algo marchita.

\section{CONTRA LA SINRAZÓN POPULISTA E INDEPENDENTISTA: CLÁUSULA DE INTANGIBILIDAD Y REVISIÓN FEDERAL DEL ESTADO CONSTITUCIONAL}

«Say something I'm giving up on you», A Great Big World song, 2013.

«Hey you, don't tell me there's no hope at all; Together we stand, divided we fall», The Wall, Pink Floyd, 1979.

A pesar de la desafección ciudadana, la democracia no está en crisis terminal y, sin embargo, tiene que revisar su definición ${ }^{49}$. Cuando parecía que todo Estado, al menos en Occidente, aceptaba las delimitaciones constitucionalistas y su desarrollo pluralista, la Gran Recesión de 2008 y sus contagios, miedos y corrupciones, hicieron reaparecer a un «fantasma» que — siempre- acompañó al concepto de democracia: el populismo ${ }^{50}$. El

46 Vid. A. López-BASAgUREn, «La secesión de territorios en la Constitución Española», Revista de Derecho de la Unión Europea, núm. 25 (2013), pp. 87-106.

47 Vid. J. Corcuera, «Soberanía y autonomía. Los límites del "derecho a decidir" (comentario a la STC 103/2008)», Revista Española de Derecho constitucional, núm. 86 (2009), pp. 303-341.

48 Aunque conviene recordar, aquí, la siguiente afirmación jurisprudencial: «Un poder que niega expresamente el derecho se niega a sí mismo como autoridad merecedora de acatamiento» (STC 114/2017, 17 octubre de 2017, FJ 5).

${ }^{49}$ Vid. Y. Papadopoulos, Democracy in Crisis? Politics, Governance and Policy, New York, Palgrave, 2013.

${ }_{50}$ Vid. G. Ionescu y E. Gellner, Populismo, Buenos Aires, Amorrortu, 1969, p. 7; J. M. Lassalle, Contra el populismo. Cartografía de un totalitarismo posmoderno, Barcelona, Debate, 2017, p. 11; M. Canovan, «Trust the People! Populism and the Two Faces of Democracy», Political Studies, núm. XLVII (1999), pp. 2-16, ÍD., The People, CambridgeUK, Polity, 2005, y J. A. SANz Moreno, «Sobre la redención populista y la fuerza constitucional: el valor intangible de la democracia», Revista de Estudios Políticos, núm. 183 (2019), pp. 161-190. 
pueblo, titular del poder en democracia, visto como puro y perfecto, exige la restitución de su soberanía ilimitada ${ }^{51}$.

La recuperación de Schmitt —en particular, de su democracia de identidad (pueblo/gobernantes, representados/representantes) y su descripción de lo político desde el antagonismo amigo-enemigo_, no ya desde la derecha populista, sino también desde su flanco izquierdo ${ }^{52}$, nos retrotrae a una dicotomía maniquea que enfrenta ese «pueblo», con poder ilimitado y voluntad propia y expresable, contra el «no pueblo», aquellos que ponen en peligro su existencia o pretenden controlar al soberano. Y, aquí, la democracia —en su definición como poder absoluto o en su comprensión constitucional como límite a los poderes del Estado- se juega su futuro.

$\mathrm{Si}$, según el conocido capricho de Goya, «el sueño de la razón produce monstruos», el amanecer electoral de la Gran Recesión ha quebra-

51 «Ustedes antes ni siquiera eran pueblo, pero ahora son el pueblo de Dios», 1 Pedro 2: 10.

52 E. Laclau, On Populist Reason, London, Verso, 2005; Ch. Mouffe, The Challenge of Carl Schmitt, London, Verso, 1999; ÍD., The Democratic Paradox, London, Verso, 2000; ÍD., Agonistics: Thinking the World Politically, London, Verso, 2013; Í. ERREJón y C. H. MouFFE, Podemos: In the Name of the People, London, Lawrence \& Wishart, 2017; M. G. SpeCTER, «What's "Left" in Schmitt? From Aversion to Appropriation in the Contemporary Political Theory», en J. MeIERHEnRICH y O. Simons, The Oxford Handbook of Carl Schmitt, New York, Oxford University Press, 2016, pp. 426-476. Las diferencias entre los populismos de derechas y de izquierda se determinan, básicamente, en la construcción antagónica del pueblo al que ambos dicen presentar: del lado de la derecha, la homogeneización en la raíz biológica, sangre y tierra para la identificación nacional; del lado de la izquierda, la distinción identificadora entre arriba y abajo, élites y masa. Los dos populismos recogen la concepción schmittiana de lo político como antagonismo existencial entre amigos/enemigos y en su plasmación democrática como identidad entre el «nosotros» frente al «ellos». Pero, tras asumir las analogías en su construcción de una identidad popular, cabe indicar las diferencias: si el populista de derechas proclama el renacer de la nación y la prevalencia de los nacionales frente al resto ( America, stronger again and first»), el populismo de izquierdas denuncia la separación entre la inmensa mayoría de damnificados y el porcentaje ínfimo de privilegiados («We are the 99 por 100»); aunque ambos desde una parte (líderes) que dice expresar la voluntad del todo (pueblo). La separación radical entre pueblo/antipueblo, nosotros/ellos, es tan absoluta en todo populismo que su discurso se convierte en cuantificación de distancia: más cerca y más lejos, con una única aproximación total, la del líder carismático que en su identidad con el pueblo- lo hace presente. La vergüenza democrática —al teologizar la política - no renegó de la omnipotencia divina, sino que trasladó el verbo hecho carne de Dios al pueblo: el grito en el nombre de Dios mutó en la voluntad del Pueblo, pero como esa voluntad tenía que ser (re)presentada, convirtió la voluntad de éstos (su/s representante/s) en el nombre del Pueblo (Í. ERrejón y C. H. Mouffe, Podemos: In the Name..., op. cit.). Aunque, para confluencias, mejor recordar las palabras de Verstrynge: «... el Pueblo es Dios en su país, es Dios en su nación. Es soberano sobre sí mismo en el actual marco de estructuración política: la Nación. Populismo implica, pues, nacionalismo...Y por eso todos los populismos son nacional-populismo. Sobraría, pues, la distinción entre Populismo y Nacional-Populismo» (J. Verstrynge, Populismo. El veto de los pueblos, España, El Viejo Topo, 2017, p. 91). 
do los grandes consensos y el Estado de partidos vigente tras la Segunda Guerra Mundial y, en consecuencia, dado alas a los populismos. La llamada racionalización del parlamentarismo no racionalizó la política ${ }^{53}$, y menos al Parlamento, pero sí fortaleció a los ejecutivos y facilitó, junto a la prelación gubernamental, la alternancia de partidos en el poder. Y, sin embargo, a pesar de mantener la retórica ontológica de la soberanía popular y la unidad nacional, se instala una nueva neutralización política con la delimitación constitucional del poder, incluso del pueblo en democracia, la garantía de derechos individuales y de las minorías y el sentido material del fundamento constitucional. Pero la vertiente conflictiva de la política siempre —-más pronto que tarde — reaparece y es aquí donde se inserta el renacer del populismo y su apego a las pulsiones, a las pasiones y, en definitiva, al mito de la pureza popular y de su voluntad ilimitada ${ }^{54}$.

53 Vid. J. A. SAnz Moreno, «Sistemas parlamentarios y gobiernos de coalición en Europa: cuando la virtud surge de la necesidad», Sistema, núm. 244 (2016), pp. 107-112.

${ }^{54}$ Entre la ingente cantidad de obras recientes sobre el populismo, cabe subrayar las siguientes: C. Mudde y C. Rovira, Populism, New York, Cambridge University Press, 2017; C. Rovira, «Populism vs. Constitutionalism?», The Foundation for Law, Justice and Society, Oxford, Oxford University Press, 2013; C. Rovira, P. Taggart, P. Ochoa y P. Ostiguy, The Oxford Handbook of populism, Oxford, Oxford University Press, 2017; B. MoffitT, «Populism and democracy: friend or foe?», The Conversation, 2015, http://theconversation. com/populism-and-democracy-friend-or-foe-rising-stars-deepen-dilemma-39695; J. B. JuDIS, The Populist Explosion, op. cit.; F. Vallespín y M. M. Bascuñán, Populismos, Madrid, Alianza, 2017, y C. DE LA TORRE, The Promise and Perils of Populism: Global Perspectives, Lexington, University Press of Kentucky, 2015, e ÍD., Populismos. Una inmersión rápi$d a$, Barcelona, Tibidabo, 2017. En especial, por su repercusión en otros estudios, conviene destacar la definición de populismo de MUDDE y ROVIRA: «a thin-centeder ideology that considers society to be ultimately separated into two homogeneous and antagonistic camps, «the pure people» versus «the corrupt elite», and which argues that politics should be an expression of the volunté générale (general will) of the people» (C. MudDE y C. ROvira, Populism, $o p$. cit., p. 6), y, aunque es una concepción ideológica criticada por VALLESPín y BASCUÑán, que reducen el populismo «a todo esfuerzo por construir comunidad a partir de diferencias y conflictos presuntamente inconmensurables; es un principio formal carente de contenido propio», es decir, que se ajustaría más al «rótulo de "lógica política", de "forma de acción política", de "estilo", "retórica"» (F. VAllespín y M. M. BASCuÑán, Populismos, op. cit., p. 67), pensamos — con JuDIs - que tratar de definir, de entrada, el populismo «as if it were a scientific term like entropy or phothosynthesis» (J. B. Judis, The Populist Explosion, op. cit., p. 13) es una equivocación. Y, sin embargo, en todo populista, con su recuperación de la política desde la distinción schmittiana amigo/enemigo, aparece una exaltación del pueblo y de la voluntad popular como titular del poder no sujeto a límite alguno; el problema es que, cuando ese titular del poder — el pueblo soberano- trata de ejercerlo, irremediablemente la supuesta democracia de identidad (del pueblo con sus gobernantes) se da de bruces con el representante o, peor, con el líder totalitario que dice ser pueblo y plasmar su voluntad. 
Sin embargo, aunque mantener la tradicional perspectiva negativa del populismo como amenaza a la democracia ${ }^{55}$ puede que no nos sirva para comprender su pujanza actual, en todo caso nos coloca ante una comprensión parcial de la política y de la democracia como voluntad omnipotente del pueblo y dicotomía social en la construcción de identidades en lucha por la hegemonía ${ }^{56}$. La proclamación del lenguaje populista como ontológicamente democrático, al definir el pueblo como soberano y, por ello, con voluntad no sujeta a restricción alguna ${ }^{57}$, confirmaría su renuncia al constitucionalismo, en cuanto límite jurídico al ejercicio del poder político y, por tanto, su abandono de la propia democracia o, peor aún, su respuesta totalitaria ${ }^{58}$. No se trata de que la vacuidad sea un dato del Derecho constitucional o una construcción política, tal y como argumenta Laclau (2005). Lo que debemos es superar ese vacío, pero no llenándolo de cualquier manera, sino de una manera democrática, en forma y contenidos.

Aquí es donde el constitucionalismo nos muestra su salida: un vínculo indivisible entre democracia y Constitución que, desde la propia forma constitucional, valida la nueva decisión constituyente como superación de la situación excepcional para la recuperación de la normalidad jurídica. Que de la democracia de identidad, en la visión schmittiana (homogeniedad sustancial), pasemos a la democracia del pluralismo ${ }^{59}$, con la consiguiente entrada de la adjetivación representativa de ese modelo democrático (art. 23.1), no significa otra cosa que la necesaria conjunción de cierta homogeneidad (histórica, nacional, de lenguas, tradiciones, culturas, religiones, etc.) con el mejor pluralismo para la conversión democrática de un pueblo que forma y desarrolla su Estado. Pero la ficción de la voluntad popular, omnipotente y total, se alza contra el orden constitu-

55 Visión negativa del populismo: sublimación de un gobierno de la mayoría a toda costa, construcción de un régimen político en el que los derechos de individuos y minorías no son respetados, la responsabilidad pública seriamente dañada y el propio rule of law en cuarentena (K. RоTH, «The Dangerous Rise of Populism», Human Rights Watch. World Report 2017, 2017, https://www.brw.org/world-report/2017/country-chapters/dangerous-riseof-populism; B. Moffiтt, The Global Rise of Populism, California, Stanford University Press, 2016; C. MudDE, «As Populist Friends or Foes of Constitutionalism», The Foundation for Law, Justice and Society, University of Oxford, 2013).

${ }_{56}$ En palabras de LACLAU: «Populism is, quite simply, a way of constructing the political» (LACLAu, On Populist Reason, op. cit., p. 6); con el pueblo definido no como un sujeto ya dado en democracia, sino como significante en construcción hegemónica por el poder.

57 Vid. C. RovirA, «Populism vs. Constitutionalism?», op. cit., pp. 1-2.

$58 \mathrm{Vid}$. A. Ramírez, La belleza de los monstruos. Acerca de qué es el populismo y por qué bay que tenerle miedo, 2015, Barcelona, Bosch, pp. 47-49.

59 Valor superior del ordenamiento jurídico con el art. 1.1 CE. 
cional y su(s) derecho(s). En su enfrentamiento se pierde toda posibilidad de desarrollo democrático de manos de totalizaciones del sujeto colectivo para sucumbir a la autocracia o, peor, al totalitarismo.

La democracia constitucional es gobierno del y por pueblo, pero va más allá de la mera gobernación popular: también es gobierno para el pueblo y, con ello, todos sus integrantes serán concebidos no solo desde la transacción entre la(s) mayoría(s) y minoría(s) que lo componen, sino también individualmente, en cuanto seres humanos y, además, ciudadanos con obligaciones y derechos. La mejor deliberación democrática podrá lograr las más apropiadas decisiones políticas, pero la mera definición procedimental de la democracia no puede desactivar todos los riesgos que supone su conversión numérica y mayoritaria sin los frenos y controles de una significación sustantiva que protege al individuo, a grupos minoritarios y, por encima de uno y otros, al conjunto de la ciudadanía y no a la mera mayoría circunstancial de sus miembros.

Aunque la emergencia de la crisis existencial que estamos viviendo —no solo a escala europea, sino mundial - arrastren a muchos ciudadanos, siguiendo los cánticos populistas, hacia la recuperación de la soberanía y de la primacía del pueblo, no podemos renunciar a la ordenación constitucional y su integración internacional. Por tanto, si la situación excepcional — siguiendo a Schmitt — precisa la vuelta del soberano y de su decisión, el populismo, apelando al pueblo frente a las élites o a los extranjeros, busca el empoderamiento de ese pueblo, pero se da de bruces con su encarnación en la representación más absoluta del líder carismático y, por ello, hace pasar la decisión del redentor por voluntad del pueblo redimido.

La política es construcción de identidades colectivas, pero va más allá de la construcción de identidades. La comprensión del discurso populista frente al institucionalista como los dos polos extremos de la determinación de la política entre los que nos vamos posicionando, permite concebir ambos como formas enfrentadas de realización democrática. Si la política se define desde la configuración de identidades colectivas y, al mismo tiempo, no se puede realizar sin el antagonismo de «los otros», esta guerra de construcciones de la parte al todo, con un todo reducido a la parte que se impone, no hace más que ensombrecer la democracia y renegar de sus valores. De ahí nuestro empeño por vincular Política y Derecho, Soberanía y Constitución, titularidad del Poder constituyente (del pueblo/nación) con sus Ciudadanos y poderes constituidos, sujetos, en democracia, a su ordenación constitucional. 
Precisamente, cuando el mecanismo ordinario de defensa de la Constitución —el Tribunal constitucional— no tiene capacidad para resolver los problemas que afronta la crisis institucional y territorial que padecemos, entramos en tiempos de reforma/revisión. Ante una situación excepcional, la superlegalidad formal de la Constitución posibilita la reaparición de un poder ya constituido en funciones constituyentes. La renovación del pacto permitirá a la ciudadanía redefinir su compromiso y sujeción a un orden constitucional fundamentado - más allá del sujeto colectivo con voluntad propia («la unidad de la Nación española» del art. 2) — en «la dignidad de la persona y los derechos inviolables que le son inherentes» (art. 10.1).

La unidad nacional se articula a través del derecho a la autonomía de nacionalidades y regiones, sin que podemos olvidar la solidaridad como principio de equilibrio entre el sujeto titular del poder —el pueblo convertido en Nación - y la pluralidad territorial de los distintos pueblos que lo integran, se llamen nacionalidad, regiones, o como quieran autocalificarse estatutariamente, pero siempre de acuerdo con la tríada constitucional: un único Estado, una sola Nación soberana, en una única Constitución, integrada y abierta al mundo. Desde aquí, la hermenéutica del TC — con sus aciertos ${ }^{60}$, fracasos ${ }^{61}$ e indefensiones del Estado constitucional ${ }^{62}$ - no puede encorsetar nuestra labor interpretativa y, mucho menos, la capacidad ciudadana para abordar su revisión constitucional. Y, ante esta urgente reforma, el valor y la defensa de la democracia deben, desde la lógica del Estado constitucional, buscar la fusión de sus vectores — popular y jurídico- en el mejor desarrollo de ambos.

En un Estado constitucional no cabe la reforma para destruir su ordenación democrática. El asalto a la democracia, desde su reducción procedimental en el nazismo, previno al constituyente posbélico y, tanto en Alemania, como en Italia o Francia, e, incluso, posteriormente, en Portugal, las cláusulas de intangibilidad explícitas se unieron a un modelo de democracia que sabe defenderse frente a sus enemigos declarados o amantes asesinos. Ahora, éstos han tomado otros nombres: sean populismos de derecha o de izquierda, sean nacional-populistas como tantos independen-

${ }^{60}$ Ejemplos: protección de derechos y primera ordenación autonómica.

${ }^{61}$ Cabe citar, aquí, de nuevo, el cerrado concepto de nación, vinculado a soberanía, cercenando la potencialidad de la expresión nacionalidad y, además la inoportunidad histórica de llevarlo al fallo en la STC 31/2010 sobre el Estatuto de Cataluña.

${ }_{62}$ Democracia sin cláusulas de intangibilidad —además, calificada como no militante- y, con ello, en una injustificable atribución al pueblo soberano de un poder ilimitado, solo constreñido formalmente al procedimiento de revisión y no fundamentado en la dignidad de la persona e integrado internacionalmente. 
tistas plebiscitarios, muchos pretenden sublimar al pueblo como poder total, no sujeto a límites. Por eso, ya que el constituyente del 78 «olvidó» incluir expresamente cláusulas de intangibilidad, una revisión de la Constitución que no quiera ser cosmética debe subrayar — de manera taxativalos límites que no pueden superarse.

Con esta justificación, nos aparece oportuno presentar nuevas redacciones de artículos para estimular el debate. Y, desde los postulados que aquí hemos esbozado, cabría realizar una profunda revisión del Título Preliminar, para que, expresamente, recogiera la fundamentación intangible de la democracia. Así, anclando al pueblo español en su integración europea e internacional, se superaría — definitivamente- la antinomia constitucional: de un lado, la soberanía popular como poder absoluto y sin frenos; de otro, el Estado constitucional como límite al poder, incluso del pueblo en democracia. Una contradicción resuelta con la conversión del pueblo (en singular) en ciudadanos y poderes públicos, todos sujetos a la Constitución y al resto del ordenamiento jurídico ${ }^{63}$.

${ }^{63}$ Con esta reconstrucción constitucional de la democracia intangible se propone la siguiente redacción para Título Preliminar: Art. 1. España se constituye en Estado Federal y Democrático de Derecho, que propugna la libertad, la igualdad, la justicia y el pluralismo como valores supremos de su ordenación jurídica, y garantiza la solidaridad entre sus Ciudadanos y Pueblos y el derecho al autogobierno de sus Comunidades Federadas. Art. 2. La dignidad y el libre desarrollo personal, sus derechos inviolables, el respeto a la ley y a los derechos de los demás son fundamentos del orden constitucional y de la paz mundial. Art. 3. La soberanía reside en el Pueblo, del que emanan todos los poderes del Estado, en su integración europea y con su participación en la Organización de las Naciones Unidas. Art. 4. Los Ciudadanos ejercen sus derechos y obligaciones, y los poderes públicos sus potestades en las formas y dentro de los límites insertos en la Constitución y el resto del ordenamiento jurídico. Art. 5. Todos los seres humanos son iguales ante la ley, sin que puedan sufrir discriminación alguna motivada por nacimiento, raza, sexo, religión, identidad nacional, idioma, situación económica, opinión política, condición social, o cualquier otra circunstancia personal o colectiva. Art. 6. Los poderes públicos promoverán la igualdad y la libertad cada vez más real y efectiva para toda la ciudadanía y, en consecuencia, entre mujeres y hombres; eliminarán los obstáculos que impiden o dificultan el pleno desarrollo de la personalidad y el ejercicio de sus derechos, y fomentarán la participación ciudadana en todas las dimensiones de la vida. Art. 7. España respeta y perfecciona el orden internacional y sus garantías humanitarias, y delimita su soberanía de conformidad con la salvaguarda de la justicia y la paz entre todos los Estados y Pueblos de la Tierra. Las normas relativas a los derechos y deberes constitucionales se interpretarán de conformidad con la Declaración Universal de Derechos Humanos y los Tratados internacionales ratificados por España, defendiendo en todo momento la protección de todos los seres humanos. Art. 8. Las normas imperativas de la ordenación mundial y todas las Convenciones internacionales, válidamente celebradas, una vez publicadas e integradas en el ordenamiento español, prevalecerán y se aplicarán, en caso de conflicto, sobre cualquier disposición normativa. Art. 9. España forma parte de la Unión Europea, con sus obligaciones y derechos, sobre la base de la reciprocidad, la subsidiariedad y la soberanía compartida de todos sus Estados, Pueblos y Ciu- 
Sin embargo, frente al nacional-populismo y su identificación de la democracia con la voluntad ilimitada de un pueblo construido como unívoco y excluyente, no cabe revisión constitucional integradora. Únicamente, aplicar y desarrollar la Constitución y, en su caso, buscar su mayor rechazo popular — sobre todo en Cataluña- y su desistimiento definitivo. Con todo, en una propuesta de reforma que busque la colaboración o, al menos, la conformidad de los nacionalismos — sean independentistas o no--, se podría plantear la posibilidad de incluir una cláusula de secesión, debidamente delimitada ${ }^{64}$. Pero, visto el panorama desalentador y rupturista del nacional-populismo en Cataluña, no se dan las condiciones mínimas para abordar, a corto o medio plazo, un debate de esta naturaleza. Sin un mínimo de lealtad constitucional es inútil plantearse la inclusión de cláusula de secesión alguna.

No obstante, y como ejercicio teórico, de darse las condiciones de sujeción al rule of law, más que plantearnos insertar una cláusula de secesión binaria en la Constitución, se puede estudiar las virtudes de una cláusula de autodeterminación interna. Esta cláusula no tiene que cumplir los requisitos propuestos por el Tribunal Supremo canadiense en su famosa Declaración sobre la independencia de Quebec. Una mayoría clara ${ }^{65}$ y, además, la negociación entre las partes ${ }^{66}$ serían asumibles, pero lo que no nos parece exportable es la necesidad de formular, en el referéndum que activa-

dadanos. Art. 10. La fundamentación constitucional y sus normas intangibles no podrán ser objeto de modificación mediante ningún procedimiento de reforma. Los poderes públicos velarán por el cumplimiento del orden constitucional y los ciudadanos tendrán el derecho de resistencia contra cualquier intento de destruirlo.

${ }^{64} \mathrm{Vid}$. mis trabajos sobre la conveniencia o maldad de la cláusula de secesión en una futura revisión de la CE que quiera contar, también, con la aquiescencia de los independentistas o, al menos, de una mayoría de la población en los territorios autonómicos con mayores cotas de nacionalismo singular, J. A. SANZ Moreno, «Identidades nacionales y ciudadanía..., op. cit.; ÍD., «Sistemas parlamentarios y gobiernos...», op. cit., p. 105, nota 18, ÍD., «Tensiones territoriales de ruptura y revisión de la Constitución española: en defensa de la democracia intangible en un Estado Federal de Derecho», Temas para el debate, núm. 281 (2018), p. 33, ÍD., «El Estado federal de los belgas: Nación y ciudadanos en su laberinto bipolar», Sistema, núm. 251-252 (2018), pp. 135-140, e ÍD., «The Myth of Ontological Foundations and the Secession Clause as Federal Answers to National Claims of External SelfDetermination», en A. López-BAsguren, Claims for Secession and Federalism, New York, Springer, 2019, pp. 347-361.

${ }^{65}$ En mayor o menor medida, pero siempre una doble mayoría: de un lado, alto porcentaje del censo para poder recontar los votos ( ¿65 por 100?), y, en caso contrario, prohibición expresa de ningún computo; y, de otro lado, una mayoría cualificada de votos (otro ¿65 por 100?). En todo caso, la secesión genera unas dualidades y fronteras tan contundentes que no puede pretenderse con mayorías irrisorias, volubles o pírricas.

${ }_{66}$ Fundamentalmente, autoridades centrales y autonómicas. 
ra el procedimiento, una pregunta también clara, si por tal se entiende una formulación polarizadora, de SI o NO a la independencia, sin más opciones y obligando al electorado a decantarse —en perverso juego de suma cero- por una u otra ${ }^{67}$. La autodeterminación extrema nos habla de secesión, pero conviene no olvidar su construcción como autogobierno territorial y/o nacional dentro del Estado español. Si todas las encuestas parecen indicar que la solución al problema que más adhesiones concita sería una mayor cota de autogobierno (autodeterminación interna), dentro del Estado español en la articulación de un modelo federal con delimitaciones diferenciales -y las sucesivas elecciones autonómicas así lo corroborar-, plantear un plebiscito binario es hacer el juego a los nacional-populistas, como si el pueblo (catalán, vasco, etc.) tuviera una única y exclusiva voluntad, cuando cada vez es más plural y, por ello, es mejor buscar la transacción y el compromiso entre sus propias mayorías/minorías. Y, como la falta de lealtad constitucional desde los ámbitos independentistas es evidente (en su única apelación a una voluntad popular como legitimación absoluta, teologizando al pueblo catalán como detentador ilimitado de todo poder), la única propuesta de reforma constitucional que cabría afrontar sería la adecuación y desarrollo del modelo autonómico a su realidad federal y —ya en el presente- asimétrica.

En esta concreción federal del Estado, esbozamos algunas propuestas:

1. Denominación estatutaria — sin estimar oportuna su inclusión expresa en la Constitución- de la auto-calificación del pueblo autonómico que más adhesiones concite — sea nación, nacionalidad, comunidad nacional, histórica, región, o cualesquiera otra se adopte-, con sujeción a un orden constitucional que desarrolla la autodeterminación interna, pero cuya voluntad soberana original y última es del conjunto de la ciudadanía española, con los límites (formales, sustantivos y de su integración europea e internacional), insertos en la propia Constitución.

2. Un Estado Federal y Plural, es decir, diferencial entre Comunidades Federadas, siguiendo el modelo asimétrico desarrollado hasta ahora, y del que - mal que pese a muchos ${ }^{68}$ - no podemos ya desprendernos. De ahí que abogamos por la desaparición del Senado y por la constitucionaliza-

${ }^{67}$ No olvidemos tampoco que la formulación de la pregunta ya puede decantar los resultados, y, además, que aquellos que reciban la positividad del SÍ tienen parte —no desdeñable- del recuento ganado.

${ }^{68}$ Empezando por el pernicioso «café para todos» como procedimiento de resolución de las reivindicaciones de las nacionalidades más singularizadas, y, continuando, por el quieras o no café, «tómate dos tazas». 
ción de mecanismos de coordinación, como la Conferencia de Presidentes Autonómicos con el Gobierno Federal e, incluso, de relaciones de bilateralidad entre Estado Federal y Comunidades Federadas para materias que sustancien - principalmente- los hechos diferenciales, tales como los «derechos históricos de los territorios forales» (DA 1. ${ }^{a}$ ), «régimen económico y fiscal del archipiélago canario» (DA 3. ${ }^{a}$ ), «lenguas» (art. 3), «seguridad pública y policías» (art. 149.1.29. ${ }^{\circ}$ ), etcétera, siempre con la expresa regulación constitucional de la lealtad federal en el ejercicio de potestades y atribuciones. Nuestra apuesta por un Estado Federal plural precisaría, también, un fortalecimiento del Congreso de los Diputados con la mejora de la proporcionalidad en una reforma de la Constitución que tenga a las Comunidades Federadas como circunscripciones electorales. Con una distribución de escaños en el que no se pierdan tantos votos por el tamaño del distrito, el sistema de reparto o la barrera electoral, la participación ciudadana vería premiada su activismo y la democracia reforzaría sus mejores defensas. En este sentido, también sería obligada una reforma en la composición y atribuciones del TC, fortaleciendo su misión como instrumento de resolución de conflictos entre las instituciones del Estado federal, y asignado a la jurisdicción ordinaria la tutela de las libertades y derechos fundamentales.

3. Distribución competencial entre Estado Federal y Comunidades Federadas a través de un sistema de lista única. Se recogerían constitucionalmente las competencias asumidas por las autoridades federales, delimitando — de la forma más reduccionista— la distinción entre legislación básica estatal y legislación autonómica de desarrollo, y, en todo caso, determinando expresamente el mínimo común regulado en las bases. El resto de las competencias quedarían en manos de las Comunidades Federadas y, por ello, se precisa fijar en la propia Constitución el marco de la autonomía municipal, permitiendo — a nivel autonómico— la supresión de la provincia en su formulación como Entidad Local.

Pero, para una revisión del calado que hemos propuesto - de un lado, la fortaleza de la democracia constitucional, con la expresa prescripción de sus fundamentos intangibles en la revisión del Título Preliminar y del Título X; de otro, el desarrollo del Estado como Federal desde el pluralismo territorial y asimétrico que nos caracterizan - los augurios siguen siendo poco halagüeños. Cuando el ideario nacionalista se convierte en religión popular, la totalización política se traslada a su resolución del problema de la relación entre identidad (colectiva) y representación (institucional), 
contaminado las instituciones con su ideal del pueblo/nación, uno y titular ilimitado del poder. La fe del creyente, sus dogmas y mitos, relegan todo discurso racional y construyen - no un solo pueblo- sino una nueva realidad, convirtiendo la ficción, la propia ensoñación, en tangible, viva y vivida. De poco vale apelar a los otros, a Europa o al mundo, la nación se siente y, de aquí, trasciende la singularidad del individuo y se proyecta como futuro anhelado. El problema es cuando la sublimación de la idea de nación al construir una nueva realidad, destruye, en su fractura, al pueblo, a la sociedad, que dice ser. El considerar al otro como «no pueblo», como «enemigo del pueblo», solo es comparable con la dicotomía radical del creyente frente al hereje ${ }^{69}$.

El salto desde la construcción (unívoca) de un pueblo/nación a la destrucción (inequívoca) de una sociedad —en su pluralidad — puede revertirse, y espero que los catalanes, por sí mismos, y los españoles, como conjunto social, todavía estamos a tiempo. Demasiadas heridas para tanto enfermo imaginario — parafraseando aquí, más que a Molière, la obra de Benedict Anderson y su imagined community (1983) — y, sobre todo, con tan pocos doctores y tan funestos aprendices de brujos. Y, lo peor, es que la solución la tenemos muy cerca: como peninsulares, en vez de más amputaciones estatales y desgarros identitarios, mejor sería dirigir nuestros esfuerzos hacia la unión con Portugal y a la mayor integración de Europa. Contra el siniestro total al que nos arrastran los egoísmos y quimeras de populistas e independentistas, menos mal que nos queda este proyecto solidario.

${ }^{69}$ En el delirio nacional-populista: del estado de servidumbre, como súbditos, a la plena libertad, personal y colectiva, es decir, a la salvación («democracia verdadera» de la República independiente como meta irrenunciable) en lucha contra el estado pecaminoso (el actual Estado social y democrático de derecho como heredero y reducto, en el presente, del régimen franquista, sic). 